\title{
NOTES ON PNEUMATOPTERIS (THELYPTERIDACEAE) FROM PAPUA NEW GUINEA, WITH THE DESCRIPTION OF A NEW CALCIPHILOUS SPECIES
}

\author{
W. TAKEUCHI \\ Arnold Arboretum and the Herbaria of Harvard University, \\ c/o PNG National Forest Authority, \\ P.O. Box 314, Lae, Morobe Province 411, Papua New Guinea
}

\section{SUMMARY}

Pneumatopteris medlerii from the Conservation International Kaijende Highlands Expedition is described. The novelty is closest to $P$. caudata, differing primarily in the short-creeping rhizome, stipitate pinnae, medial sori, glabrous indusia, and the occurrence on limestone. Noteworthy records for P. petrophila and P. nephrolepioides are also reported with the new species.

Key words: Thelypteridaceae, Pneumatopteris, limestone karst.

\section{INTRODUCTION}

Recent explorations in the Kaijende Highlands of Enga Province (Papua New Guinea) have revealed the presence of many taxa previously unknown to science. The expeditionary discoveries include an apparently new amphibian genus (S. Richards, pers. comm.), a new mammal (C. Helgen, pers. comm.), and numerous distributional records. Pneumatopteris medlerii is the first of the botanical novelties to be presented from these multidisciplinary surveys of the Central Ranges (Fig. 1,2).

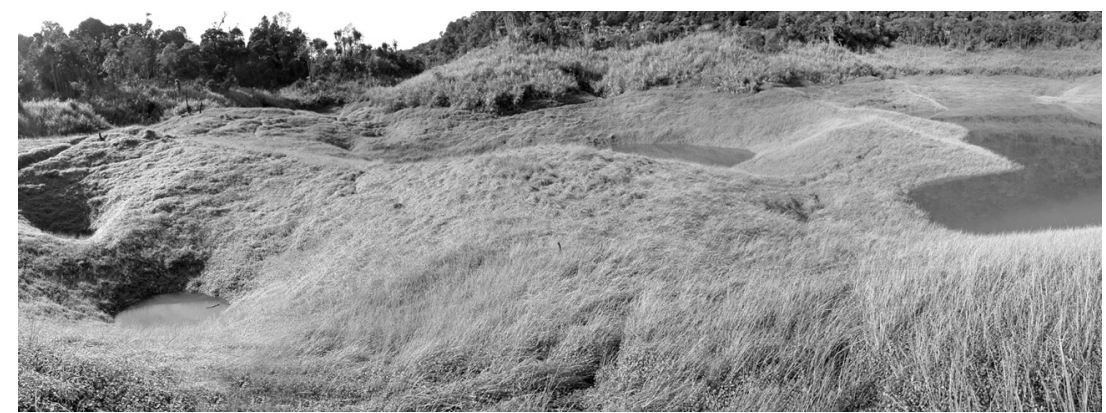

Fig. 1. Paiela. The limestone zone is perforated by sinkholes (Australian Survey Corps, 1979). During periods of high rainfall, the catchment lake-overflow disappears into a series of large funnelform holes (shown with residual water) adjacent to the bivouac. Drainage rates are very high; a new lake which formed after torrential rains was completely removed by the sinkholes after three days. An extensive subterranean plumbing probably underlies the whole district, as there are no surface outflows anywhere near the basin. 


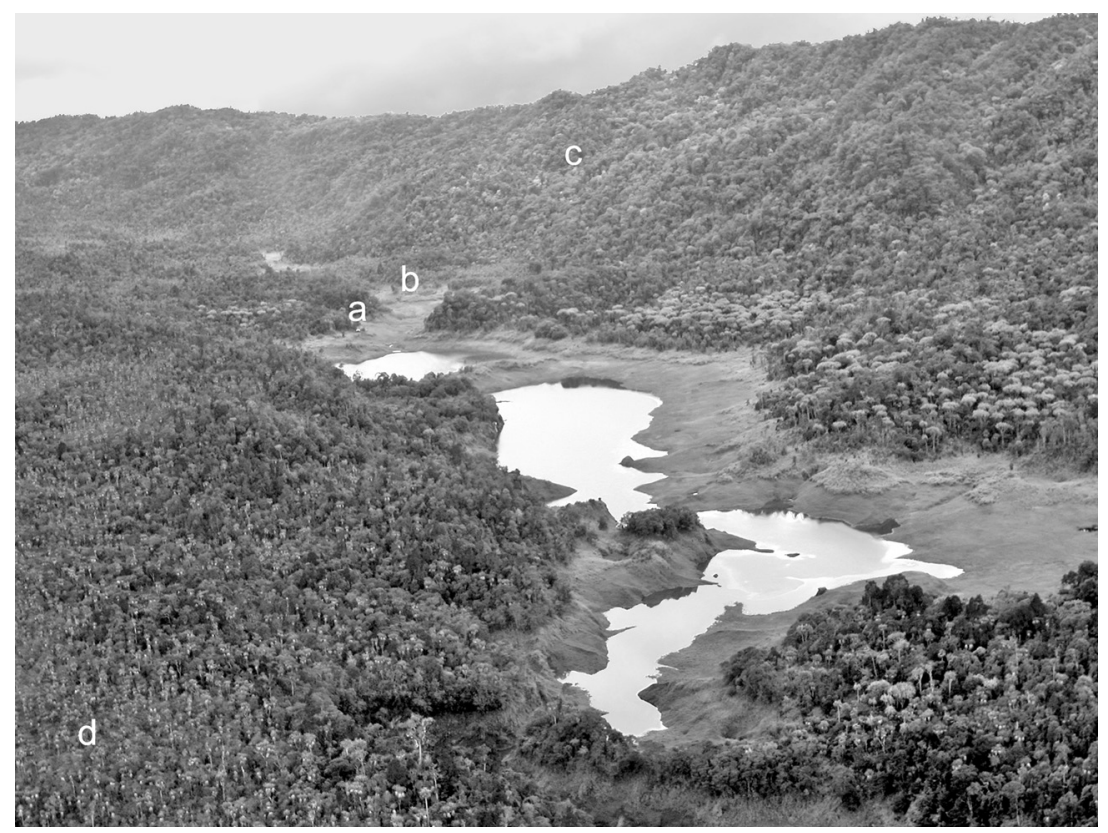

Fig. 2. Paiela (Lake Tawa, Kaijende Highlands), type locality for Pneumatopteris medlerii. Aerial view of the catchment lakes and surrounding terrain. a. Expedition bivouac; $b$. sinkholes; c. collection site on limestone exposures; d. Pandanus savannah to the north of camp.

\section{DESCRIPTION}

Pneumatopteris medlerii W. Takeuchi, spec.nov. - Fig. 3, 4; Map 1

Affinis P. caudata (Holttum) Holttum sed rhizoma breviter repens; pinnis inferioribus, basi angustatis; sori mediales; indusia glabra; sporangia pilis brevibus capitatis ornata differt. - Typus: Takeuchi, Towati \& Ama 19947 (holo LAE; iso A, BISH, CANB, K, L), Papua New Guinea, Enga Province, Paiela bivouac, alt. 2600 m, 30 August 2005.

Epilithic ferns. Rhizome short-creeping, 2-2.5 mm diam., contorted or not, usually furnished with persisting stipe bases from fallen leaves; scales appressed, lax, opaquely fuscous, suborbicular, cellular detail invisible. Stipes $(8-) 13.5-20.5(-25.5) \mathrm{cm}$ by $0.2-0.8 \mathrm{~mm}$, channelled on the dorsal side, rounded beneath, stramineous, discolorously marked by the callose residue of old scales, otherwise smooth on most surfaces; scales crowded at the stipe base, absent from distal intervals, falling early, peltate, glabrous, appressed, ovate-orbicular or irregular, chartaceous, dark brown with black centres, cells thin-walled, \pm isodiametric; hair indument papilliform, septate, hyaline, suberect, confined to the dorsal channel; aerophores obscure. Lamina bipinnatisect, narrow, usually of even width, (3-)4.9-7(-9.3) cm wide; rachis (13.5-) $18-30.5 \mathrm{~cm}$ long, pallid, glabrous to the naked eye; scales absent; hair indument as for the stipe but denser, distributed on upper and lower surfaces, papillate or subulate, antrorsely arcuate to patent; aerophores black-punctate or invisible; pinnae conform, alternate, 11-17 per 
side, lowermost $1(-3)$ pairs reduced, passing abruptly or gradually to $1-3(-6)$ rudimentary auricles on the stipe, (or without highly reduced pinnae); frond apex attenuate, pinnatisect, usually $1-2.5 \mathrm{~cm}$ caudate. Largest pinnae 37-57(-67) by (6-) 9-14 mm, at the lamina centre separated (10-)15-24(-29) mm from adjacent segments, lanceolate, falcate, decurrent on a c. $1.5 \mathrm{~mm}$ stipe, never sessile, base manifestly unequal, lower

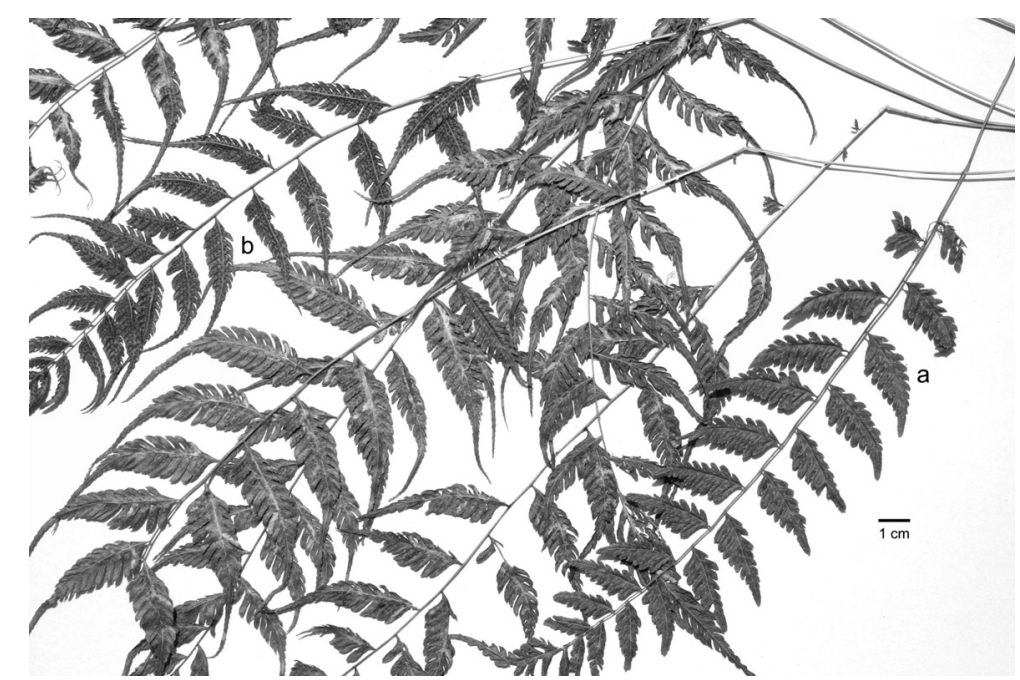

Fig. 3. Pneumatopteris medlerii W. Takeuchi. a. Juvenile pinnae; b. fertile pinnae (Takeuchi, Towati \& Ama 19947).

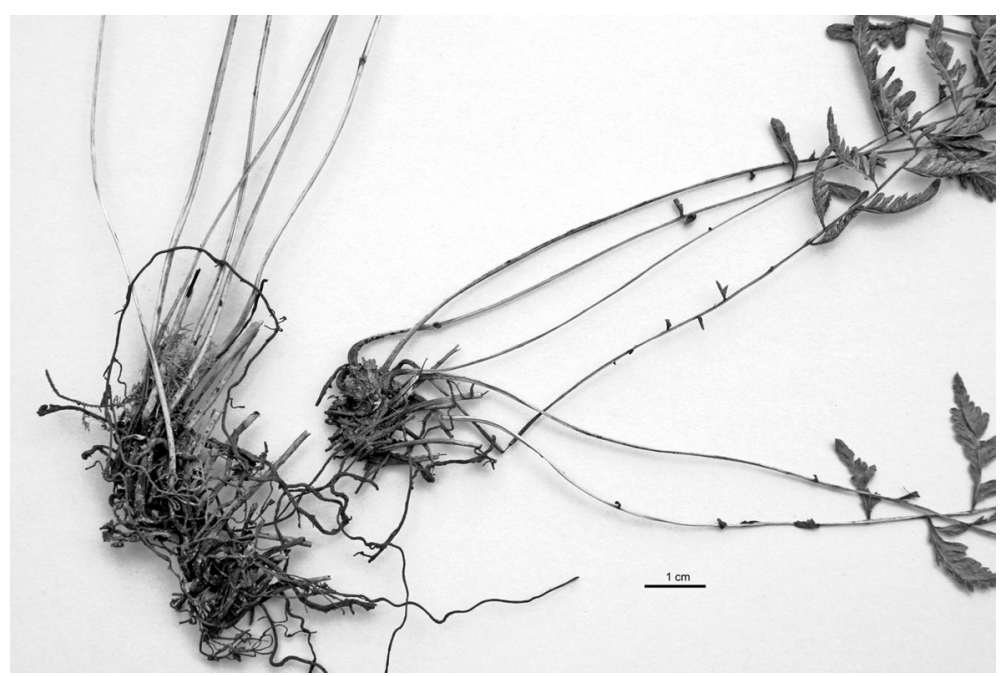

Fig. 4. Pneumatopteris medlerii W. Takeuchi. Stipe bases and the close-creeping rhizome (Takeuchi, Towati \& Ama 19947). 


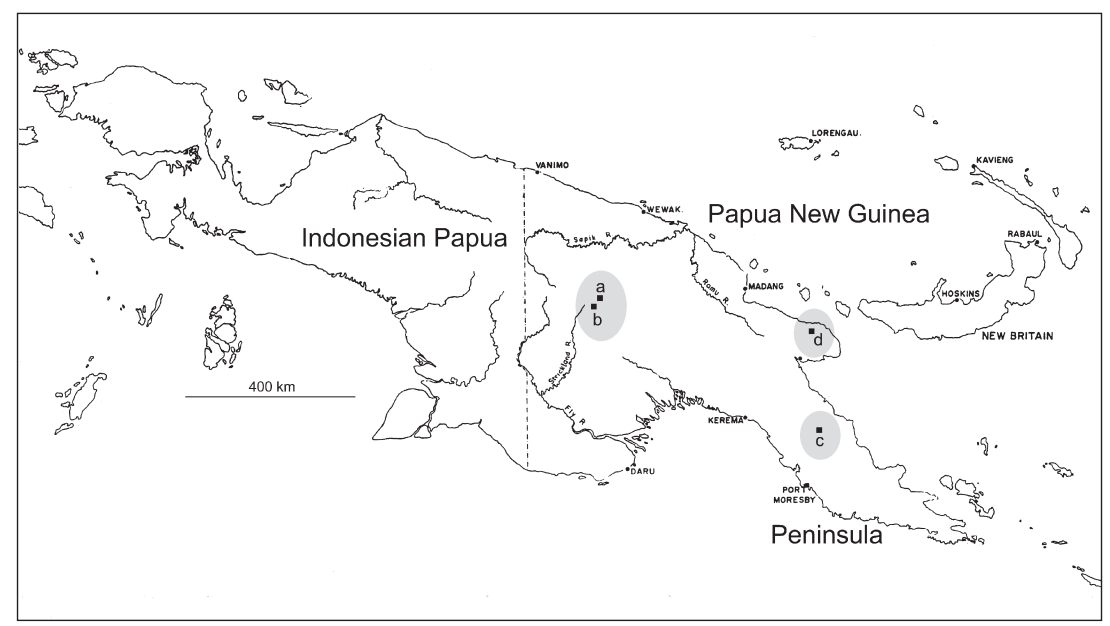

Map 1. Island of New Guinea. Localities mentioned in the text. a. Paiela (Lake Tawa); b. Karius limestone; c. Mafulu, type locality for P. nephrolepioides; d. Sambangan (spelled as 'Sambanga' in Holttum).

side severely contracted, acroscopic side subtruncate or oblique; margins laxly ciliate; lobes oblongish, acute or obtuse, sinuate or obscurely toothed, falcate, usually parted to within 1-1.5 $\mathrm{mm}$ from the midrib; pinna apex caudate, serrulate, to $4 \mathrm{~cm}$ by $1-3$ $\mathrm{mm}$; adaxial costae (or costulae) laxly acicular-puberulent, abaxial surfaces with widely scattered capitate hairs along veins, glabrescent. Venation pinnate, free, vein groups 3-13-nerval, basal acroscopic nerves ending in the sinus, basal basiscopic nerves ending immediately above; costules $2.5-3.5(-4) \mathrm{mm}$ apart, diverging $55-75^{\circ}$ from midribs; costae prominent, adaxially channelled; higher order nervation bifacially prominulous; copiously pustulate between veins. Sori medial or inframedial, (1-)3-8(-10) per vein group, not paraphysate, sporangia provided with minute capitate hairs. Indusia glabrous, persisting as a folded residue after spore discharge.

Field notes - Fronds projecting horizontally from the edge of limestone overhangs; stipes green; pinnae chartaceous, bifacially light green.

Distribution - Known only from the type locality.

Habitat \& Ecology - Epilithic calciphiles on karst exposures, in mossy montane forest.

Etymology - The new fern is named after Jane Ann (Kurtenacker) Medler (19122003), the late curator of pteridophytes at the B.P. Bishop Museum in Honolulu.

Notes - 1. Papuasian Pneumatopteris are represented in herbaria mostly by moderately large species such as $P$. costata, $P$. kesseriana, $P$. rodigasiana, $P$. sogerensis, and the $P$. superba-subappendiculata complex ( $P$. superba and $P$. subappendiculata are probably conspecific, judging from contemporary collections with intergrading characters (e.g., Takeuchi 10490, 10545)). Most of the small Papuasian species are represented only by their types. Among the congeners closest to P. medlerii in overall aspect, five out of eight are known from single collections (see species under couplet 1b; Holttum, 1981). 
Because of a lack of adequate samples for determining variation within species, Holttum's characterization of certain taxa was necessarily very preliminary. Some of the resulting difficulties are reflected in $P$. medlerii, for which the closest relationship is to $P$. caudata, even though the presumed affinity may not be readily apparent from the existing conspectus.

In order for the novelty to be accommodated in Holttum (1981: 418), two separate modifications are required. First, at couplet 47 the following continuation should be added under the lead for $P$. versteeghii:

47a. Pinna apex obtuse; indusia short-hairy $\ldots \ldots \ldots \ldots \ldots \ldots$ P. versteeghii

b. Pinna apex caudate; indusia glabrous $\ldots \ldots \ldots \ldots \ldots \ldots \ldots$ P. medlerii

Secondly, because fronds with larger pinnae will key out closest to couplet 51, the lead for P. caudata needs to be similarly altered as follows:

51a. Caudex erect; pinnae sessile; sori supramedial; indusia furnished with short erect hairs; sporangia glabrous . . . . . . . . . . . . . . . caudata

b. Rhizome close-creeping; pinnae never sessile; sori medial or inframedial; indusia glabrous; sporangia with minute capitate hairs . . . . . . . . . P. medlerii

2. Holttum's pioneering work in Pneumatopteris will require revisiting as more specimens become available from New Guinea. This will be especially true for the epilithic species, which remain poorly understood and are collectively more rangerestricted than their terrestrial congeners in forest understories.

The new species was growing with P. petrophila (Takeuchi et al. 19953), an infrequently collected fern previously unrecorded from limestone.

A distributional record was also obtained for the calciphilous P. nephrolepioides, from the Karius kegelkarst near Paiela (Takeuchi et al. 19239). This second congener

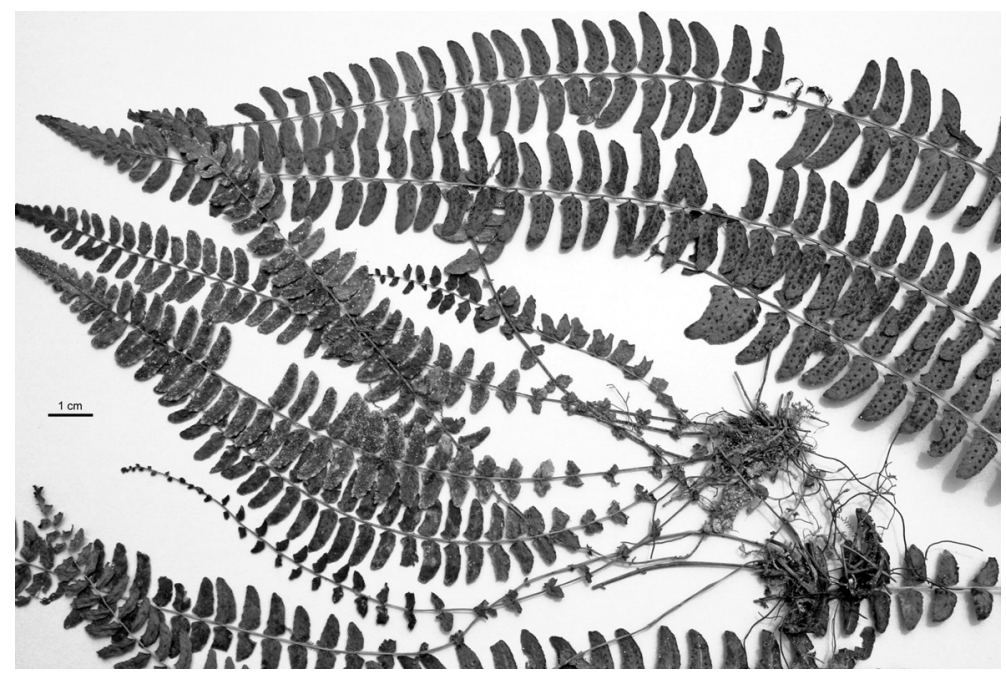

Fig. 5. Pneumatopteris nephrolepioides. Unmounted duplicate from the Karius limestone (Takeuchi, Towati \& Jisaka 19239). 
was previously known by two collections originating at Mafulu in Central Province and at Sambangan in Morobe Province (Holttum, 1973: 320).

Pneumatopteris nephrolepioides is probably the easiest member of its genus to identify. The diminutive pinnae with calcium concretions are very characteristic and strikingly similar to Nephrolepis (Fig. 5). Although the Karius number has smaller pinnae ( 8 by $4 \mathrm{~mm}$ ) than the typical facies, it otherwise conforms precisely to the description in Holttum (1973: 320; 1981: 431).

\section{ACKNOWLEDGEMENTS}

My activities in Papuasian botany are supported by the National Science Foundation (grant DEB 0315930), the Arnold Arboretum, and the Herbaria of Harvard University.

\section{REFERENCES}

Australian Survey Corps. 1979. Papua New Guinea 1:100,000 topographic survey map. Edition 1-AAS, series T601: Koroba 7486.

Holttum, R.E. 1973. Studies in the family Thelypteridaceae V. The genus Pneumatopteris Nakai. Blumea 21: 293-325.

Holttum, R.E. 1981. Thelypteridaceae. Flora Malesiana, Ser. II, 1: 331-599. 